
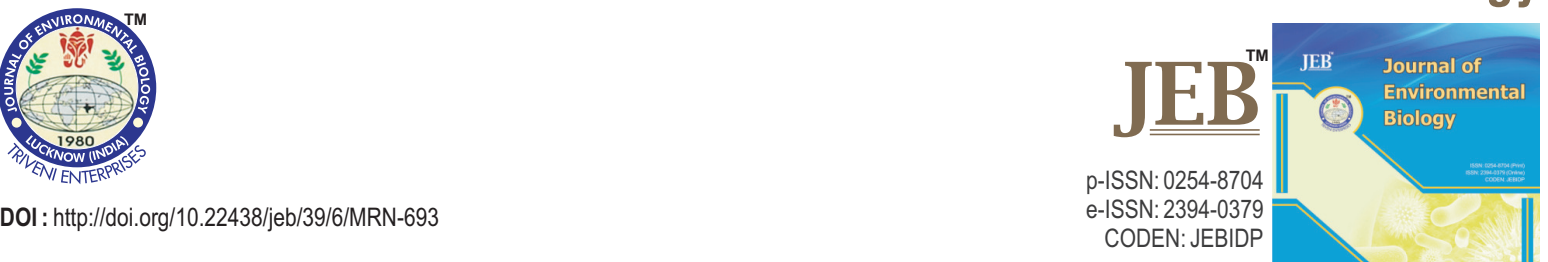

\title{
Endophytic bacteria from root nodules of Ormosia macrocalyx with potential as plant growth promoters and antifungal activity
}

\section{Authors Info \\ L.Hernández-Hernández ${ }^{2}$, J.T. Coutiño-Megchun', C.I.Rincón-Molina', V.M. Ruíz-Valdiviezo', J.M.Culebro-Ricaldi', R.I. Cruz-Rodríguez, H.H.Palomeque-Dominguez and R.Rincón-Rosales ${ }^{1 *}$ \\ 'Laboratorio de Ecología Genómica. Tecnológico Nacional de México/Instituto Tecnológico de Tuxtla Gutiérrez. Carretera Panamericana km. 1080, C.P. 29050, Tuxtla Gutiérrez, México \\ ${ }^{2}$ División Académica de Ciencias Biológicas. Universidad Juárez Autónoma de Tabasco, México \\ *Corresponding Author Email : reriro61@hotmail.com}

Key words

Antagonism

Bioinoculum

Endophytes

Nitrogen fixation

Plant growth promoting bacteria

Publication Info Paper received : 13.07 .2017 Revised received : 10.12 .2017 Re-revised received : 23.01 .2018 Accepted : 12.02 .2018

\begin{abstract}
Aim: The present study was carried out to determine the diversity of cultivable endophytic bacteria associated to leguminous Ormosia macrocalix, and selected strains with potential as plant growthpromoting bacteria (PGPB) and antifungal activity.
\end{abstract}

Abstract

Methodology: The isolated microorganisms were characterized using morphological, physiological and biochemical tests. The genetic diversity and phylogeny of isolated microorganisms were revealed by ERICPCR and sequencing of $16 \mathrm{~S}$ rDNA. The plant growth promoting ability, plant inoculation assays and test for antagonism were evaluated to know the potential as plant growth-promoting bacteria.

Results : The amount of 105 endophytic bacteria was extracted from the root nodules of legume. According to the phenotypic characteristics and phylogenetic analysis based on 16S rDNA sequences, these strains were grouped within the bacterial genera Bacillus, Citrobacter, Enterobacter, Novosphingobium, Paenibacillus, Pantoea and Ensifer. Due to the capacity for nitrogen fixation, auxin production, phosphate solubilization and antagonism against certain pathogenic fungi were confirmed to be done by the plant growth promoting bacteria. The isolate of Pantoea sp. CA-02 produced the highest concentrations of IAA and Ensifersp. CA-14 showed the maximum nitrogen fixation potency. The Bacillus sp. CA-11 and Pantoea sp. CA-02 isolates exhibited higher degree of phosphate solubilization. Isolate CA-02 showed ability to inhibit the pathogenic fungi Fusarium oxyporum and $F$. solani. The fungus Fusarium verticilloides was strongly inhibited by isolate of Citrobactersp. CA-15.

Interpretation: Bacterial endophytes have potential use as bio-inoculants for the cultivation and propagation of leguminous tree $\mathrm{O}$. macrocalyx. Use of endophytes may be particularly important in growing plants with high biological potential for reintroduction into their natural habitat.

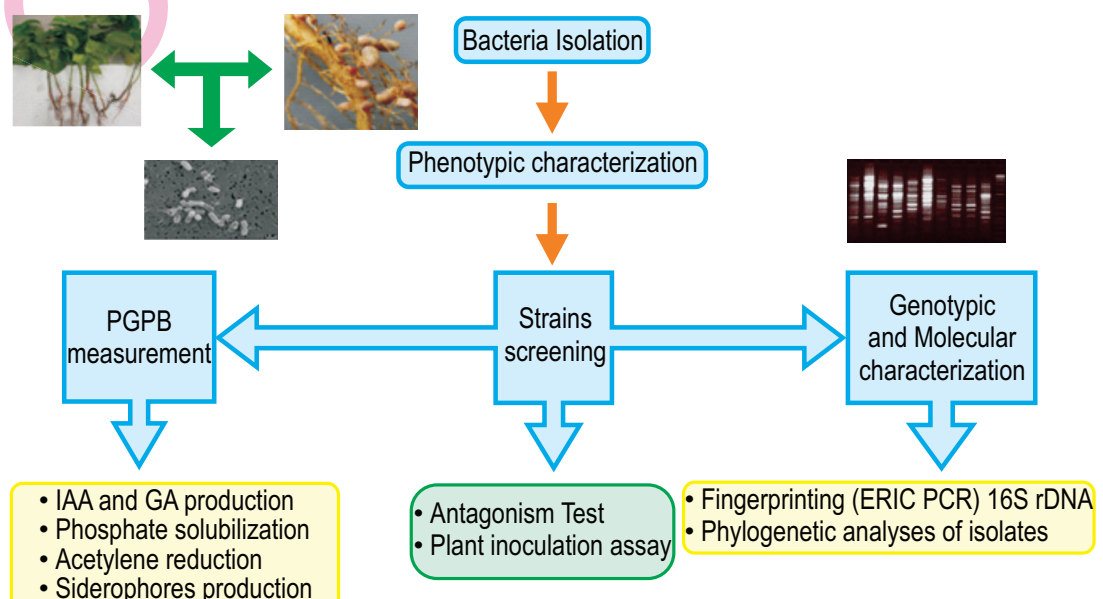




\section{Introduction}

The leguminous trees play an important ecological role in the functioning and productivity of terrestrial ecosystems in tropical forest, considering the capability of these plants to fix atmospheric nitrogen in association with a broad variety of rhizobacteria (Wang et al., 2006).

Ormosia macrocalyx Ducke (Fabaceae), commonly known as caracolillo, is a nodulating leguminous tree (Cernusak et al., 2011) occurring in tropical forests ranging from southern Mexico to Panama. This legume is highly appreciated by the Mexican Mayan communities due to its wood quality, foliage and seeds, which are used in crafts (Pérez-Hernández et al., 2011) and to the restoration of degraded areas because of its leafy canopy (Gonçalves et al., 2011). Deforestation, excessive logging and fires have reduced populations of 0 . macrocalyx. According to the Mexican official standard NOM-059-ECOL2001, this tree is under special protection as it is a species legume threatened with extinction (DOF, 2011). Therefore, programs aimed at reforestation of 0 . macrocalyx have been undertaken. However, when the seedlings are grown under greenhouse conditions, these are often attacked by pathogenic fungi, mainly by Fusarium species, which cause severe root rot and leaf wilt (Ozbay and Newman, 2004; Culebro-Ricaldi et al., 2017), making plants have slow growth and high mortality rate (PérezHernández et al., 2011). To solve this problem, farmers have commonly used systemic fungicides, but to the limited extent. On the contrary, these treatments have contributed to environmental pollution, as these chemicals are persistent and highly toxic (Bawa, 2016). The PGPB microorganisms were used for the biological control of phytopathogenic fungi this has led to a promising potential strategy to reduce the use of agrochemicals (Martínez-Rodríguez et al., 2014). The PGPBs may be isolated from different plant parts: roots, nodules, leaves, flowers and sprouts of legumes and contribute to plant growth (Rosenblueth and Martínez-Romero, 2006). Some PGPBs can enter the interior of root nodules of the legume and establish endophytic populations. Endophytic microbes promote plant growth by helping plants acquire nutrients, e.g. by way of nitrogen fixation, phosphate solubilizing mechanism or iron chelation, by preventing pathogen infections via antifungal or antibacterial agents, by outcompeting pathogens for nutrients by siderophore production, or by imparting systemic resistance in plants (Dudeja et al., 2012).

In addition to rhizobia, a wide range of cultivable endophytic bacteria have been isolated, mainly from different herbaceous legume such as alfalfa, clover, soybean and peanut (Stajkovic, 2009, Ibáñez et al., 2009). Also, endophytic bacteria have been isolated from leguminous trees. For instance, Citrobacter, Enterobacter, Erwinia, Klebsiella, Pantoea and Salmonella, and were isolated from nodules and bark tissues of Conzattia multi flora (Wang et al., 2006). Some of these bacteria significantly promoted the growth of Conzattia seedlings. In another study, thirty-nine endophytic bacterial strains were isolated from the nodules of Lespedeza sp. and 16S rDNA sequences grouped the bacteria into the following nine different genera: Arthrobacter, Bacillus, Bradyrhizobium, Burkholderia, Dyella, Methylobacterium, Microbacterium, Rhizobium and Staphylococcus. Most of the isolates showed various plant growth promoting activity (Palaniappan et al., 2010). These studies on endophytic bacterial diversity have revealed the existence of many species that can establish an association with leguminous trees. On the other hand, the Leguminosae family includes more than 18000 known species and nodulation has only been investigated in a small fraction of these plants (Sprent, 2001). It is important to trace endophytes in other species of leguminous tree in order to determine their potential use as PGPBs.

The present study aimed to characterize the diversity of cultivable endophytic bacteria associated with the legume 0 . macrocalyx, and to determine their beneficial capability in promoting growth, as well as their antifungal activity against pathogenic fungi.

\section{Materials and Methods}

Isolation of bacteria from nodules: The isolates were obtained from the root nodules of $O$. macrocalix, a native legume species that grows in the rainforest of an ecological reserve of Nacajuca, Tabasco, Mexico. The root nodules were collected from young seedlings. Nodules were carefully washed under sterilized water by immersing them in $95 \%$ ethanol for $5 \mathrm{~min}$, followed by immersing them $5 \%$ is sodium hypochlorite solution for $10 \mathrm{~min}$ and finally rinsing eight times with sterile water. The surfacesterilized root nodules were crushed in a sterile plate, and bacteria were isolated by streaking the nodule extraction using yeast extract-mannitol (YEMA) medium. The petri dishes were incubated aerobically at $28^{\circ} \mathrm{C}$ for 5 days. The developed bacterial colonies were purified by streaking single colonies on the same media and then these were examined microscopically. The pure cultures were preserved at $4^{\circ} \mathrm{C}$ temporarily in $65 \%$ glycerol-YM broth at $80^{\circ} \mathrm{C}$ for long term storage.

Phenotypic characterization: The characterization of isolates were carried out on YEMA medium. The tolerance of salt was evaluated at $28^{\circ} \mathrm{C}$ with $0.5,1.0,2.0,3.0$ and $5.0 \%(\mathrm{w} / \mathrm{v}) \mathrm{NaCl}$ concentrations, while the $\mathrm{pH}$ levels were determined at 4.0, 5.0, 9.0 and 11.0. The production of acid or alkali was evaluated on the same medium by adding with $25 \mathrm{mg} \mathrm{ml}^{-1}$ bromothymol blue as a $\mathrm{pH}$ indicator. Antibiotic resistance was tested following the process recommended by Martínez-Romero et al. (1991). In addition, aluminum and copper tolerance of the isolates were analyzed in solid YEMA medium.

DNA extraction and fingerprinting (ERIC-PCR): The DNA genomic was isolated according to the manufacturer's 
specifications during the DNA Isolation Kit $\left(\mathrm{ROCHE}^{\circledR}\right.$, Basel, Switzerland). PCR primers ERIC 1R and ERIC2 were used to study the genomic fingerprinting (Versalovic et al., 1994).

16S rRNA gene sequencing and phylogenetic analysis: PCR was performed with the bacterial universal 16S rDNA primers $f$ D1-5'AGAGTTTGATCCTGGCTCAG 3' and rD15'AAGGAGGTGATCCAGCC 3' (Weisburg et al., 1991). Before sequencing, the amplification mixture was purified using the Roche ${ }^{\circledR}$ PCR product purification system. All sequences were compared using BLAST (Altschul et al., 1990) and were aligned by the CLUSTAL X (2.0) software (Larkin et al., 2007). Phylogenetic and molecular evolutionary analyses were done with MEGA v5.2 software. The phylogenetic tree was constructed by Neighbour-Joining model (Saitou and Nei, 1987; Tamura et al., 2011). Finally, the $16 S$ rRNA gene sequences were deposited in the GenBank database.

Plant growth promoting ability of the isolates: Solubilization of phosphate was analyzed as described by Nautiyal (1999). The IAA concentration from each isolate were determined by using HPLC equipment. The gibberellins $\left(\mathrm{GA}_{3}\right)$ produced by the isolates were determined by a colorimetric method as described by Holbrook et al. (1961). All isolates were tested for siderophore production by the Chrome Azurol S (CAS) plate assay. The fixing nitrogen of the isolates was determined by acetylene reduction activity (ARA) assay.

Plant inoculation assays: The selected isolates from each bacterial groups, identified previously by $16 \mathrm{~S}$ rDNA gene sequence analysis, were used as inoculants. Ormosia macrocalyx seeds were scarified with $\mathrm{H}_{2} \mathrm{SO}_{4}$ for 15 min and surface sterilized with $1 \%(\mathrm{v} / \mathrm{v})$ sodium hypochlorite for $10 \mathrm{~min}$. Treated seeds were subjected to germination on $0.8 \%$ agar Petri dishes. The germinated seedlings were planted in pots filled with peat moss and enriched with free $\mathrm{N}$ medium and placed in a plant growth chamber. The plants were inoculated with $2 \mathrm{ml}$ of bacterial suspension with a concentration of $1 \times 10^{6} \mathrm{CFU} \mathrm{m}{ }^{-1}$ (Bashan,

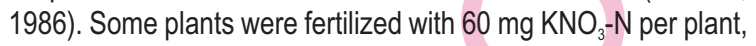
and uninoculated plants were used as a control. Experimental units were distributed under a completely randomized design, while the evaluations were repeated four times. After 60 days, the plants were harvested and estimated for the plant height, plant fresh weight and root fresh weight. The total plant nitrogen content was determined by Kjeldahl method (Bremner and Mulvaney, 1982).

Antifungal activity: Fusarium oxysporum (Genbank accession number KX232463) was obtained from CIAD-Culiacán fungal collection, F. solani (Genbank accession number HQ530551) was obtained from CIAD-Culiacán fungal collection and $F$. verticillioides (Genbank accession number G1982311.1) was obtained as a monoconidial culture isolate from maize were used for antifungal activity tests. The bacteria were grown on YEM medium and incubated at $28^{\circ} \mathrm{C}$ for $24 \mathrm{hr}$. The fungus were grown on a potato dextrose agar medium on a plate at $28^{\circ} \mathrm{C}$ for 7 days in dark condition. A mycelial fragment $(0.8 \mathrm{~cm}$ diameter) of fungus was placed at the center of the Petri dish with PDA medium, then each bacterial isolate was inoculated to confront at a distance of 3 $\mathrm{cm}$ in the same Petri dish. The plates were then incubated at $28^{\circ} \mathrm{C}$ in dark conditions for 5 days and the inhibition percentage was determined following the method of Martínez-Rodriguez et al. (2014).

Statistical analysis: The significance of the effect of the isolates on inoculation and antifungal activity, P-solubilizing, IAA and gibberellins production, as well as ARA activity was determined by ANOVA, and the treatment mean was tested for significance with the Tukey test $(P<0.05)$.

\section{Results and Discussion}

Legumes play an important role in the functionality and productivity of these natural systems in tropical forests, when considering the capacity of these legumes to capture essential nutrients, such as nitrogen and phosphorus, symbiotically with different bacterial species (Pajares and Bohannan, 2016). In this study, a total of 105 isolates were obtained from O. macrocalyx root nodules. The isolates were grouped by ERIC-PCR into 16 genomic fingerprints. The isolates showed different patterns which were considered for sequencing and phylogenetic analysis.

Based on 16S rDNA gene sequences, O. macrocalyx nodule isolates were classified into seven bacterial genera, as Bacillus, Citrobacter, Enterobacter, Paenibacillus, Pantoea, Ensifer and Novosphingobium (Table 1). Isolates CA-10, CA-11 and $\mathrm{CA}-13$ were grouped into the genus Bacillus. Isolate CA-15 was affiliated within the genus Citrobacter and had $86.4 \% 16 \mathrm{~S}$ rDNA gene sequence similarity with Citrobacter farmeri CDC 2991-81. Isolate CA-03 was grouped within the genus Enterobacter and showed $95.1 \%$ similarity with $E$. asburiae JCM6051. Isolates CA-01, CA-04, CA-09 and CA-12 were clustered within of the genus Paenibacillus. CA-01 had $99.9 \%$ similarity with $P$. lupini RLAHU15, while isolate CA-04 and CA-12 showed $96.9 \%$ similarity with $P$. cineris LMG 18439 . Isolates CA02, CA-05, CA-06, CA-07 and CA-08 were grouped into the genus Pantoea. Up to $99 \%$ of the CA-02 and CA-08 sequences were identical to $P$. agglomerans, while CA-05, CA-06 and CA-07 showed similarity with sequences of $P$. dispersa. Finding an isolate related to the genus Ensifer, isolate CA-14 had a 98.0\% genetic similarity with E. mexicanus ITTG R7. This was also an important outcome, since these species has been reported as a bacterium with high potential to fix nitrogen (Lloret et al., 2007). The isolate CA-16 was grouped with members of the genus Novosphingobium. This taxonomic status of all the identified isolates was confirmed using phylogenetic analysis of the complete sequences of gene 16S rDNA (Fig 1). Likewise, the 
Table 1: Molecular identification of endophytic isolates of O. macrocalyx Ducke

\begin{tabular}{|c|c|c|c|c|c|}
\hline Isolate name & Accession No. & $\begin{array}{l}\text { 16S rRNA } \\
\text { sequence (bp) }\end{array}$ & Closely NCBI match & $\begin{array}{l}\text { Species identity } \\
\text { BLAST(\%) }\end{array}$ & Class \\
\hline CA-01 & KX389680 & 1169 & Paenibacillus lupini RLAHU15 (NR_134115) & 99.0 & Bacilli \\
\hline CA-02 & KX389676 & 1240 & Pantoea agglomerans 76 (AM184097) & 94.0 & y-proteobacteria \\
\hline CA-03 & KX389685 & 1329 & Enterobacter asburiae JCM6051 (AB004744) & 95.1 & Y-proteobacteria \\
\hline CA-04 & KX389681 & 1248 & Paenibacillus cineris LMG 18439 (AJ575658) & 96.6 & Bacilli \\
\hline CA-05 & KX389678 & 1271 & Pantoea dispersa R7-534 (JQ659886) & 99.0 & y-proteobacteria \\
\hline CA-06 & KX389678 & 1202 & Pantoea dispersa R7-534 (JQ659886) & 97.5 & Y-proteobacteria \\
\hline CA-07 & KX389679 & 1313 & Pantoea dispersa LMG 2603 (DQ504305) & 85.5 & Y-proteobacteria \\
\hline CA-08 & KX389677 & 1244 & Pantoea agglomerans PB17 (EU360112) & 99.0 & y-proteobacteria \\
\hline CA-09 & KX389682 & 1334 & Paenibacillus catalpa D75(HQ657320) & 95.2 & Bacilli \\
\hline CA-10 & KX389693 & 1113 & Bacillus subtilisLD170 (KJ534453) & 80.0 & Bacilli \\
\hline CA-11 & KX389690 & 1211 & Bacillus niacinilF015566 (AB021194) & 99.0 & Bacilli \\
\hline CA-12 & KX389683 & 1220 & PaenibacilluscinerisLMG 18439 (AJ575658) & 96.9 & Bacilli \\
\hline CA-13 & KX389691 & 1322 & Bacillus megateriumIAM 13418 (D16273) & 97.1 & Bacilli \\
\hline CA-14 & KX389671 & 1254 & Ensifermexicanus ITTGR7 (DQ411930) & 98.0 & a-proteobacteria \\
\hline CA-15 & KX389688 & 1266 & CitrobacterfarmeriCDC2991-81 (AF025371) & 86.4 & y-proteobacteria \\
\hline CA-16 & KX389684 & 1312 & NovosphingobiumresinovorumNCIB87 (EF029110) & 95.5 & a-proteobacteria \\
\hline
\end{tabular}

Table 2: Representative groups of endophytic isolates of $O$. macrocalyx, according to ERIC_PCR profiles

\begin{tabular}{lllll}
\hline Group No. & Bacterial genus & Isolates & Number of isolates & Representative isolate \\
\hline I & Bacillus & CA-10CA-11CA-13 & 3 & CA-11 \\
II & Citrobacter & CA-15 & 1 & CA-15 \\
III & Enterobacter & CA-03 & 1 & CA-03 \\
IV & Novosphingobium & CA-16 & 1 & CA-16 \\
V & Paenibacillus & CA-01CA-04CA-09CA-12 & 4 & CA-12 \\
VI & Pantoea & CA-02CA-05CA-06CA-07CA-08 & 5 & CA-02 \\
VII & Ensifer & CA-14 & 1 & CA-14 \\
\hline
\end{tabular}

study of genomic fingerprints, as well as phylogenetic analysis allowed to determine that there is a wide diversity and abundance of bacterial species associated with 0 . macrocalyx. Several of these bacteria could be considered as plant growth-promoting bacteria (PGPB).

Later, a representative of each one of the bacterial entophytes (Table 2) was selected to perform several studies related to phenotypic characterization and to the biological potential of strains as PGPB. The highest number of endophyte isolates were Gram-negative, aerobic, non-spore, forming rods, and they grew faster in YEMA medium. Bacterial cells formed colonies with various sizes and colors. About $85 \%$ of isolates had the capacity to form pigments and abundant exopolysaccharides (EPS). The EPS forms a protective layer for the bacteria, which allows tolerance to abiotic stress and contributes to the colonization of root surface (Sandhya and Ali, 2015). All isolates can grow well at $37^{\circ} \mathrm{C}$ and $44^{\circ} \mathrm{C}$, with the exception of Ensifer sp. CA-14 and Novosphingobium sp. CA-16, which showed little growth at higher temperatures (Table 3). Most of the isolates have capacity to grow in the range from $\mathrm{pH} 5.0$ to 9.0. The Pantoea sp. $\mathrm{CA}-02$ stood out for its capacity to grow in the range from $\mathrm{pH} 4.0$ to
11.0. For tolerance to $\mathrm{NaCl}$, endophytic isolates have the ability to grow in the range from 0.5 to $3.0 \%$, except Paenibacillus sp. CA12. This result is important due to salinity because it is one of the most severe environmental problems affecting the crop yield and it has been shown that most cultivations are sensitive to higher salinity of soil. Therefore, PGPB microorganisms can be used as an alternative to improve soil fertility. In relation to the antibiotic test, Citrobacter sp. CA-15 showed more ability to tolerate different antibiotics tested, as compared to other isolates (Table 3). Furthermore, it was found that all isolates had the capacity for tolerance of higher concentrations of $\mathrm{Al}^{+3}$ and $\mathrm{Cu}^{+2}$. Also, this study shows that all isolates were able to produce siderophores. Siderophore-producing rhizobacteria are also known to convey induced systemic resistance to plants and suppressiveness to the soil, and have been implicated in the biocontrol of several plant diseases (Saha et al., 2016).

The potential of endophytic isolates from O. macrocalyx root nodule as PGPB was evaluated based on the ability to solubilize phosphate, fix nitrogen, and to biosynthesize auxins (IAA) and gibberellins $\left(\mathrm{GA}_{3}\right)$. The Pantoea sp. CA-02 isolate produced a higher concentration of IAA $\left(6.19 \mathrm{mg} \mathrm{l}^{-1}\right)$ and of $\mathrm{GA}_{3}$ 
Table 3: Characteristics of endophytic isolates of 0 . macrocalyx Ducke

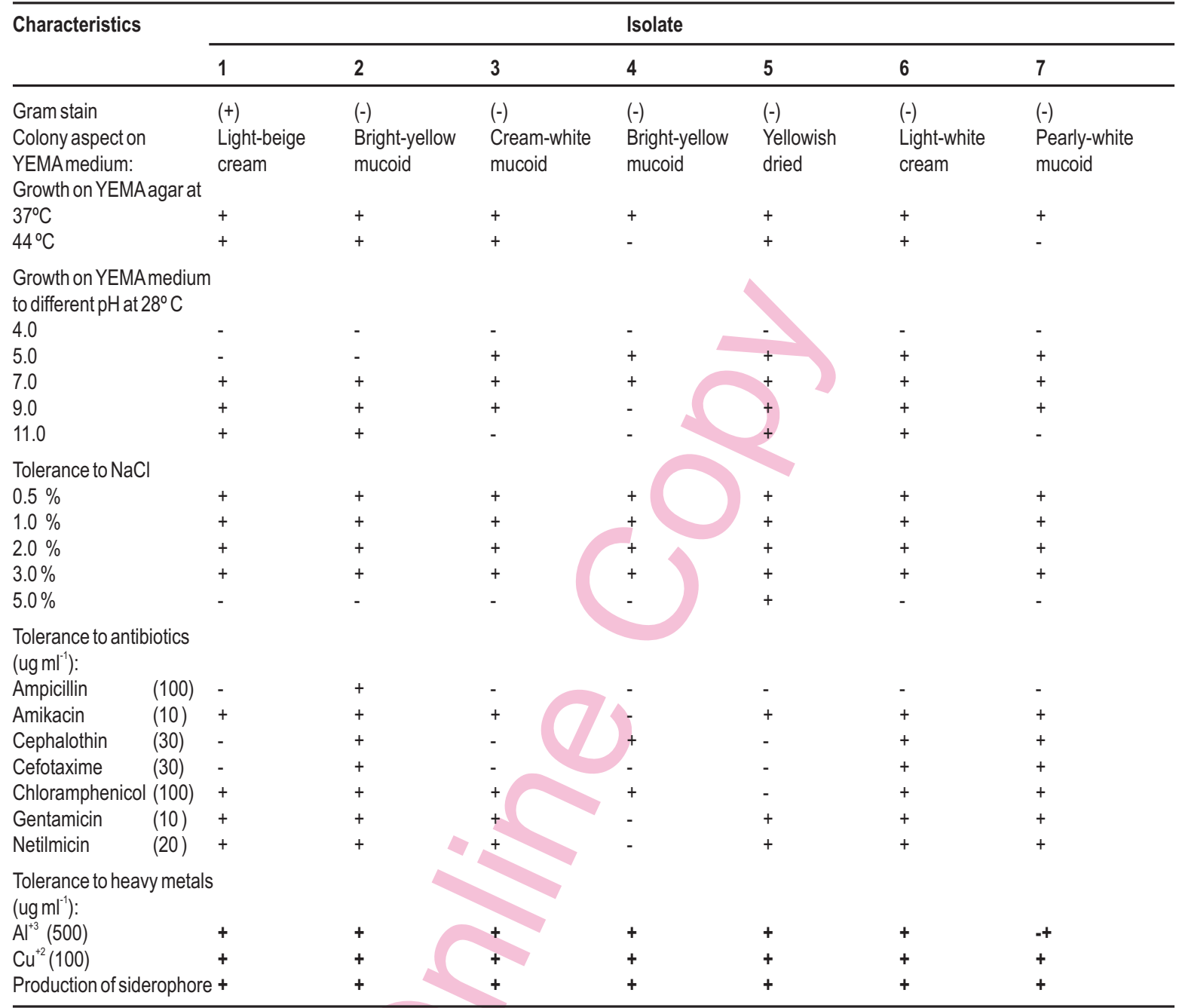

Taxon 1, Bacillus sp. CA-11; 2, Citrobacter sp. CA-15; 3, Enterobacter sp. CA-03; 4, Novosphingobium sp. CA-16; 5, Paenibacillus sp. CA-12; 6 , Pantoeasp. CA-02, and 7, Ensifersp.CA-14. +, Positive; -, Negative

Table 4 : IAA and GA production, phosphate solubilization and acetylene reduction activity (ARA) of endophytic isolates of O. macrocalyx Ducke

\begin{tabular}{lllll}
\hline Isolate & IAA $\left(\mathrm{mg} \mathrm{l}^{-1}\right)$ & GA $\left(\mathrm{mg} \mathrm{l}^{-1}\right)$ & P-solubilization $\left(\mathrm{mg} \mathrm{I}^{-1}\right)$ & ARA $^{\boldsymbol{1}}$ \\
\hline Bacillus sp. CA-11 & $15.2 \mathrm{~B}^{\S}$ & $3.97 \mathrm{BC}$ & $37.8 \mathrm{~A}$ & $242.3 \mathrm{BC}$ \\
Citrobactersp. CA-15 & $5.7 \mathrm{D}$ & $2.97 \mathrm{C}$ & $13.3 \mathrm{D}$ & $106.1 \mathrm{C}$ \\
Enterobactersp. CA-03 & $10.3 \mathrm{C}$ & $3.05 \mathrm{C}$ & $25.5 \mathrm{BC}$ & $627.4 \mathrm{AB}$ \\
Novosphingobium sp. CA-16 & $10.4 \mathrm{C}$ & $2.82 \mathrm{C}$ & $24.2 \mathrm{C}$ & $804.3 \mathrm{~A}$ \\
Paenibacillus sp. CA-12 & $12.0 \mathrm{C}$ & $3.95 \mathrm{BC}$ & $31.2 \mathrm{AB}$ & $740.7 \mathrm{~A}$ \\
Pantoea sp. CA-02 & $19.6 \mathrm{~A}$ & $6.22 \mathrm{~A}$ & $36.9 \mathrm{~A}$ & $751.5 \mathrm{~A}$ \\
Ensifersp. CA-14 & $16.7 \mathrm{~B}$ & $4.47 \mathrm{~B}$ & $32.0 \mathrm{AB}$ & $821.3 \mathrm{~A}$ \\
HSD $^{*}(\mathrm{P}<0.05)$ & 2.16547 & 1.39203 & 6.95898 & 471.36 \\
\hline
\end{tabular}

${ }^{8}$ Mean values of three replicates. Means followed by same letter are non significant (Tukey test, $\left.P<0.05\right) ;{ }^{\pi}$ ARA: acetylene reduction assay $\left(\mu\right.$ mol $\mathrm{C}_{2} \mathrm{H}_{4}$ per culture fresh weigh $\left.h^{-1}\right) ;{ }^{*} H S D$ : Honest Significant Difference 


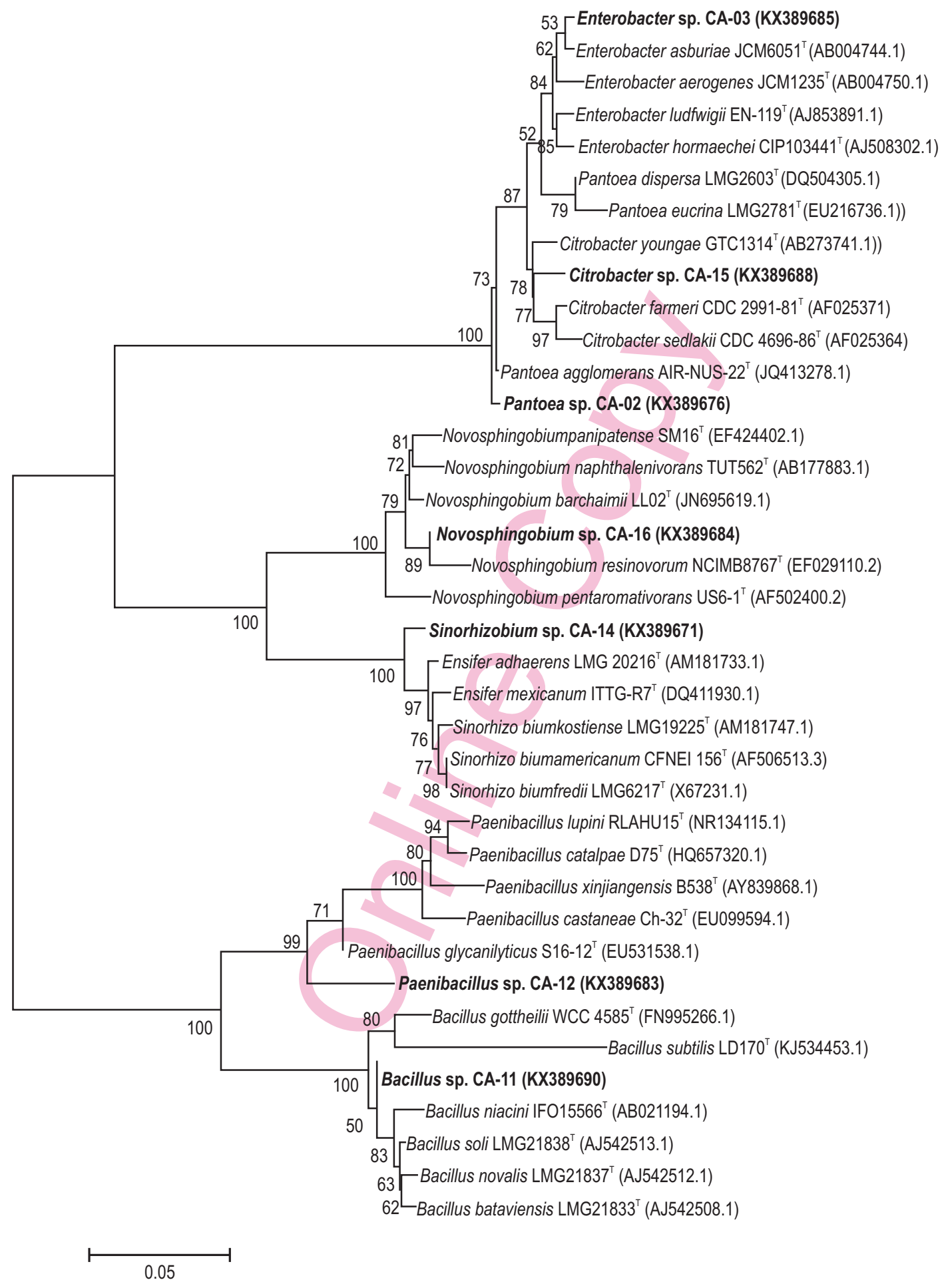

Fig. 1 : Phylogenetic tree based on 16 S rDNA gene sequences of representative endophytic strains isolated from Ormosia macrocalyx. The accession numbers for the sequences are indicated within parentheses. Those generated in this study are shown in bold. 

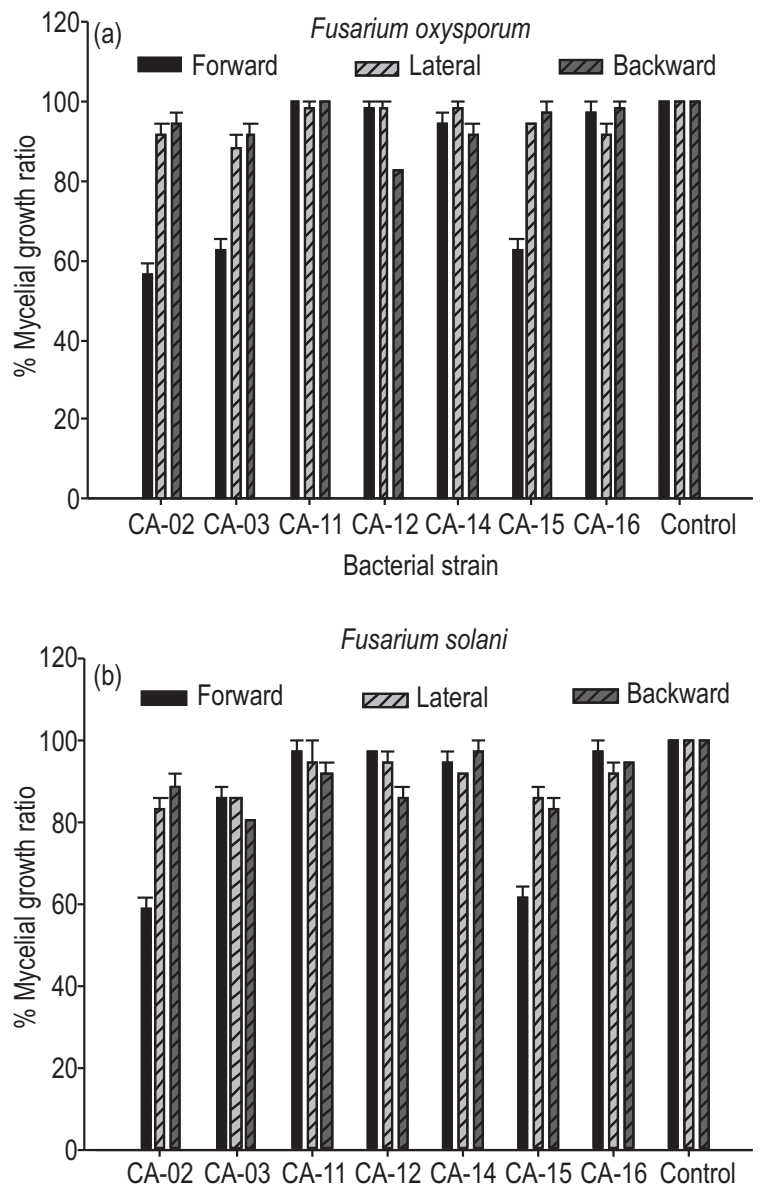

Bacterial strain

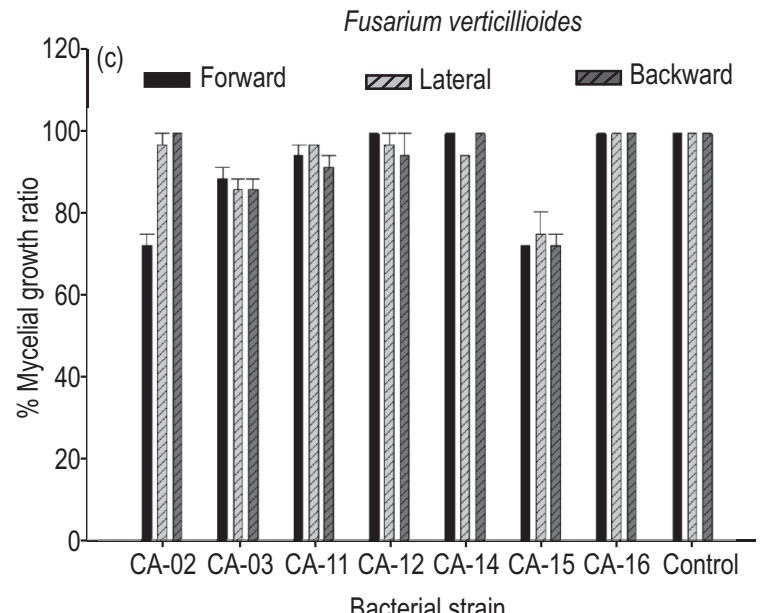

Fig. 2: Quantification of phytophatogenic fungi Fusarium oxysporum, Fusariu solani and Fusarium oxysporum forward, lateral and backward mycelial growth ratio in the CA-02, CA-03, CA-11, CA-12 CA-14, CA-15 and $\mathrm{CA}-16$ strains. Vertical bars represent SD of mean of three replications.
(6.22 $\mathrm{mg} \mathrm{l}^{-1}$ ) as compared to the other isolates (Table 4). IAA and $\mathrm{GA}_{3}$ are important plant hormones and play a significant role in plant growth (Singha et al., 2017). Bacillus sp. CA-11 showed a higher capacity to solubilize phosphate $\left(37.8 \mathrm{mg} \mathrm{l}^{-1}\right)$, followed by Pantoea sp. isolate CA-02 (29.8 $\left.\mathrm{mg} \mathrm{I}^{-1}\right)$. Additionally, the Ensifer sp. CA-14 exhibited maximum capacity for nitrogen-fixation in comparison to other isolates (Table 4). Therefore, in this study all endophytic isolates have potential to biosynthesize IAA, $\mathrm{GA}_{3}$ and solubilize phosphate, as well as the ability for nitrogen fixation. These results suggest that nitrogen and phosphorus are important nutrients for the development and metabolism of 0 . macrocalyx legume.

Inoculation of selected isolates had significant effect on the growth of 0 . macrocalyx plants (Table 5). The inoculated plants with endophyte isolates increased significantly the total height and fresh weight, while the root weight and total nitrogen content for inoculated plants with Ensifer sp. CA-14 were significantly higher in comparison to the control plants $(P<0.05)$.

Antifungal activity: The results revealed that Pantoeasp. CA02, Enterobactersp.CA-03, Citrobactersp. CA-15 and Paenibacillus sp. CA-12 exhibited inhibition against $F$. oxysporum (Fig 2). Isolate CA-02 showed the strongest inhibition against mycelial growth (40\%), CA-03 and CA-15 reduced growth (35\%), while CA-12 inhibited mycelial growth (18\%). The isolates that exhibited inhibition against $F$. solani were CA-02, CA-03, CA-15, CA-12 and Ensifer sp. CA-14. Isolates CA-02 and CA-15 showed the strongest inhibition against mycelial growth $38.5 \%$ and $35.5 \%$, respectively. The inhibition of lateral mycelial growth was significant with CA-02 and CA-03 reducing 13.7\%, while CA-03 and CA-15 inhibited $19.2 \%$ and $15.7 \%$ mycelial growth, respectively. The growth of $F$. verticillioides was inhibited with the isolates CA- 02,CA-03, CA-11 and CA-15. The latter significantly inhibited forward (28.4\%), lateral (19.2\%) and backward (21.9\%) mycelia growth, compared to control. CA-03 showed inhibition against mycelial forward growth at $24.7 \%$. Mousa et al. (2015) reported that a species of Citrobacter and three isolates of Paenibacillus had antifungal activity against pathogenic Fusarium isolates of maize. Choi et al. (2008) indicated that Paenibacillus produces fusaricidin compounds, polyketides and non-ribosomal peptides that hold back fungal pathogens. The results of this study is similar to the study of Martínez-Rodríguez et al. (2014) who reported Bacillus sp.inhibited the growth of $F$. oxysporum, which indicated that inhibition of lateral and backward growth was related to the volatile compounds released.

In conclusion, the present study provides valuable information about the phenotypic and genotypic diversity of endophytic bacteria associated with Ormosia macrocalyx. It was found that bacterial isolates belong to the genera Bacillus, Citrobacter, Enterobacter, Novosphingobium, Paenibacillus, Pantoea and Ensifer. All endophytic isolates had the capacity for nitrogen fixation, production of IAA and $\mathrm{GA}_{3}$, solubilization of 
Table 5: Growth parameters and total nitrogen content of $O$. macrocalyx plants inoculated with endophytic isolates

\begin{tabular}{lllll}
\hline Treatment & Plant height $(\mathbf{c m})$ & Plant fresh weight $\mathbf{( g )}$ & Root fresh weight $(\mathbf{g})$ & Total shoot nitrogen (mg per plant) \\
\hline Uninoculated & $30.42 \mathrm{~B}^{\text {§ }}$ & $2.73 \mathrm{AB}$ & $1.18 \mathrm{C}$ & $73.32 \mathrm{D}$ \\
Bacillus sp. CA-11 & $32.02 \mathrm{~B}$ & $2.97 \mathrm{AB}$ & $1.57 \mathrm{BC}$ & $100.02 \mathrm{BCD}$ \\
Citrobactersp. CA-15 & $31.35 \mathrm{~B}$ & $2.75 \mathrm{AB}$ & $1.49 \mathrm{C}$ & $98.97 \mathrm{BCD}$ \\
Enterobactersp. CA-03 & $30.57 \mathrm{~B}$ & $2.32 \mathrm{~B}$ & $1.12 \mathrm{C}$ & $77.4 \mathrm{D}$ \\
Novosphingobium sp. CA-16 & $38.82 \mathrm{~A}$ & $3.20 \mathrm{~A}$ & $1.45 \mathrm{C}$ & $85.2 \mathrm{CD}$ \\
Paenibacillus sp. CA-12 & $38.70 \mathrm{~A}$ & $3.15 \mathrm{~A}$ & $2.03 \mathrm{AB}$ & $96.67 \mathrm{BCD}$ \\
Pantoeasp. CA-02 & $40.32 \mathrm{~A}$ & $3.12 \mathrm{~A}$ & $1.97 \mathrm{AB}$ & $146.47 \mathrm{AB}$ \\
Ensifersp. CA-14 & $41.80 \mathrm{~A}$ & $3.45 \mathrm{~A}$ & $2.07 \mathrm{~A}$ & $175.92 \mathrm{~A}$ \\
$\mathrm{KNO}_{3}-\mathrm{N}(60$ mg per plant) & $41.52 \mathrm{~A}$ & $3.13 \mathrm{~A}$ & $1.96 \mathrm{AB}$ & $135.25 \mathrm{ABC}$ \\
HSD $^{*}(\mathrm{P}<0.05)$ & 4.70362 & 0.8053 & 0.46687 & 53.3467 \\
\hline
\end{tabular}

${ }^{8}$ Mean values of four replicates. Means followed by same letter are non-significant (Tukey test, $\left.P<0.05\right) ;{ }^{*} H S D$ : Honest Significant Difference

phosphate and showed antifungal activity against pathogenic fungi. Therefore, these bacterial endophytes could be promising bioinoculants to enhance cultivation and reforestation of 0 . macrocalyx legume.

\section{Acknowledgment}

Thank to the 'Tecnologico Nacional de Mexico', projects No. 6211.17-P and 6212.17- $P$ ' for the financial support of this work.

\section{References}

Altschul, S.F., W. Gish, W. Miller, E.W. Myers and D.J. Lipman: Basic local alignment search tool. J. Mol. Biol., 215, 403-410 (1990).

Bashan, Y.: Significance of timing and level of inoculation with rhizosphere bacteria on wheat plants. Soil Biol. Biochem., 18, 297 301 (1986).

Bawa, I.: Management strategies of Fusarium wilt disease of tomato incited by Fusarium oxysporum f. sp. lycopersici (Sacc.): A review. Int. J. Acad. Res., 2, 32-42 (2016).

Bremner, J.M. and C.S. Mulvaney: Nitrogen-total: Methods of soil and plant analysis. J. Am. Soc. Agron., 9, 595-624 (1982).

Cernusak, L.A., K. Winter, C. Martinez, E. Correa, J. Aranda, M. García, C. Jaramillo and B.L. Turner: Responses of legume versus non legume tropical tree seedlings to elevated $\mathrm{CO}_{2}$ concentration. Plant Physiol., 157, 372-385 (2012).

Culebro-Ricaldi, J.M., V.M. Ruiz-Valdiviezo, M.A. Rodríguez-Mendiola, M.E. Ávila-Miranda, F.A. Gutiérrez-Miceli, R.I. Cruz-Rodríguez, L. Dendooven and J.A. Montes-Molina. Antifungal properties of Beauveria bassiana strains against Fusarium oxysporum f.sp. lycopersici race 3 in tomato crop. J. Environ. Biol., 38, 821-827 (2017).

Choi, S.K., S.Y. Park, R. Kim, C.H. Lee, J.F. Kim and S.H. Park: Identification and functional analysis of thefusaricid in biosynthetic gene of Paenibacillus polymyxa E681. Biochem. Biophys. Res. Commun., 365, 89-95 (2008).

DOF: Diario Oficial de la Federación. Norma Oficial Mexicana NOM-059ECOL-2001. Especies y subespecies de flora y fauna silvestres terrestres y acuáticas en peligro de extinción. SEGOB. México, pp. 25(2011)

Dudeja, S.S., R. Girl, R. Saini, P. Suneja-Madan and E. Kothe: Interaction of endophytic microbes with legumes. J. Basic Microbiol., 52, 248260 (2012).

Gonçalves, E.P., F.S. de Jesus Soares, S. dos Santos Silva, D. de Souza Tavares, J.S. Viana and B.C.C. Cardoso: Dormancy breaking in Ormosia arborea seeds. Int. J. Agron., 2011 (2011). doi:10.1155/ 2011/524709.

Holbrook, A., W. Edge and F. Bailey: Spectrophotometric method for determination of gibberellic acid. Adv. Chem. Ser., 28, 159-167 (1961).

Ibáñez, F., J. Angelini, T. Taurian, M.L. Tonelli and A. Fabra: Endophytic occupation of peanut root nodules by opportunistic Gamma proteobacteria. Syst. Appl. Microbiol., 32, 49-55 (2009).

Larkin, M.A., G. Blackshields, N.P. Brown, R. Chenna, P.A. McGettigan, H. Mc William, F. Valentin, I.M. Wallace, A. Wilm, R. Lopez, J.D. Thompson, T.J Gibson and D.G. Higgins: Clustal W and Clustal X version 2.0. Bioinformatics, 23, 2947-2948 (2007).

Lloret, L., E. Ormeño-Orrillo, R. Rincón-Rosales, J. Martínez-Romero, M.A. Rogel- Hernandez and E. Martínez-Romero: Ensifer mexicanus sp. nov. a new species nodulating Acacia angustissima (Mill.) Kuntze in México. Syst. Appl. Microbiol., 30, 280-290 (2007).

Martínez-Romero, E., L. Segovia, F.M. Mercante, A.A. Franco, P. Graham and M.A. Pardo: Rhizobium tropici, A novel species nodulating Phaseolus vulgaris $L$. beans and Leucaena sp. trees. Int. J. Syst. Bacteriol., 41, 417-426 (1991).

Martínez-Rodríguez, J.C., M. De la Mora-Amutio, L.A. PlascenciaCorrea, E. Audelo-Regalado, F.R. Guardado, E. HernándezSánchez, Y.J. Peña-Ramírez, A. Escalante, M.J. Beltrán-García and T. Ogura: Cultivable endophytic bacteria from leaf bases of Agave tequilana and their role as plant growth promoters. Braz. J. Microbiol., 45, 1333-1339 (2014).

Mousa, W.K., C.R. Shearer, V. Limay-Rios, T. Zhou and M.N. Raizada: Bacterial endophytes from wild maize suppress Fusarium graminearum in modern maize and inhibit mycotoxin accumulation. Front. Plant Sci., 6, 805 (2015).

Nautiyal, C.S.: An efficient microbiological growth medium for screening phosphate solubilizing microorganisms. FEMS Microbiol. Lett., 70, 265-270 (1999).

Ozbay, N. and S.E. Newman: Fusarium crown and root rot of tomato and control methods. Plant Pathol. J., 3, 9-18 (2004).

Pajares, S. and B.J.M. Bohannan: Ecology of nitrogen fixing, nitrifying, and denitrifying microorganisms in tropical forest soils. Front. Microbiol., 7, 1045 (2016). 
Palaniappan, P., P.S. Chauhan, V.S. Saravanan, R. Anandhan and T. Sa: Isolation and characterization of plant growth promoting endophytic bacterial isolates from root nodule of Lespedeza sp. Biol. Fertil. Soils., 46, 807-816 (2010).

Pérez-Hernández, I., S. Ochoa-Gaona, G. Vargas-Simón, M. MendozaCarranza and N.A. González-Valdivia: Germinación y supervivencia de seis especies nativas de un bosque tropical de Tabasco, México. Madera y Bosques., 17, 71-91 (2011).

Rosenblueth, M. and E. Martínez-Romero: Bacterial endophytes and their interactions with hosts. MPMI., 19, 827-837 (2006).

Saha, M., S. Sarkar, B. Sarkar, B.K. Sharma, S. Bhattacharjee and P. Tribedi: Microbial siderophores and their potential applications: A review. Environ. Sci. Pollut. Res. Int., 23, 3984-3999 (2016).

Saitou, N. and M. Nei: The neighbor-joining method: A new method for reconstructing phylogenetic trees. Mol. Biol. Evol., 4, 406-425 (1987).

Sandhya, V. and Sk. Z. Ali: The Production of exopolysaccharide by Pseudomonas putida GAPP45 under various abiotic stress conditions and its role in soil aggregation. Microbiol., 84, 512-519 (2015).

Singha, B., P.B. Mazumder and P. Pandey: Characterization of plant growth promoting rhizobia from root nodule of Mimosa pudica grown in Assam, India. J. Environ. Biol., 38, 441-447 (2017).

Sprent, J.I.: Nodulation in Legumes. Royal Botanic Gardens, Kew, London (2001).

Stajkovic, O.: Isolation and characterization of endophytic non-rhizobial bacteria from root nodules of alfalfa (Medicago sativa L.). Bot. Serbia, 33, 107-114 (2009).

Tamura, K., D. Peterson, N. Peterson, G. Stecher, M. Nei and S. Kumar: MEGA 5: Molecular evolutionary genetics analysis using maximum likelihood, evolutionary distance, and maximum parsimony methods. Mol. Biol. Evol., 28, 2731-2739 (2011).

Versalovic, J., M. Schneider, J.F. Brujin and J.R. Lupski: Genomic fingerprinting of bacteria using repetitive sequence-based polymerase chain reaction. Methods Mol. Cell Biol., 5, 25-40 (1994).

Wang, E.T., Z.Y. Tan, X.W. Guo, R. Rodríguez-Duran, G. Boll and E. Martínez-Romero: Diverse endophytic bacteria isolated from a leguminous tree Conzattia multiflora grown in Mexico. Arch. Microbiol., 186, 251-259 (2006).

Weisburg, W.G., S.M. Barns, D.A. Pelletier and D.J. Lane: 16 S ribosomal DNA amplification for phylogenetic study. J. Bacteriol., 73, 697-703(1991) 